\title{
Steam-PCM heat exchanger design and materials optimization by using Cr-Mo alloys
}

\author{
F. Javier Ruiz-Cabañas ${ }^{1, *}$, Cristina Prieto ${ }^{1}$, Aleix Jové ${ }^{1}$, Virginia Madina ${ }^{2}$, A. Inés Fernández ${ }^{3}$, \\ Luisa F. Cabeza ${ }^{4}$ \\ ${ }^{1}$ Abengoa Research, C/ Energía Solar n ${ }^{\circ}$ 1, Palmas Altas, 41014, Sevilla, Spain \\ ${ }^{2}$ Materials for Energy and Environment Unit. Tecnalia Research and Innovation, Mikeletegi \\ Pasealekua, 2, 20009 San Sebastián, Spain \\ ${ }^{3}$ Department of Materials Science \& Physical Chemistry, Universitat de Barcelona, Martí i
}

Franqués 1-11, 08028 Barcelona, Spain

${ }^{4}$ GREiA Research Group, INSPIRES Research Centre, Universitat de Lleida, Pere de Cabrera s/n, Lleida, Spain

* Corresponding author:

F. Javier Ruiz-Cabañas

Abengoa Research, C/ Energía Solar nº 1, Palmas Altas, 41014-Sevilla

Phone: 0034954996570

Cell: 0034618125761

Email: fjavier.ruiz@abengoa.com

\begin{abstract}
A387 Gr 91 Cr-Mo alloy corrosion compatibility with LiOH-KOH mixture was evaluated at 315 ${ }^{\circ} \mathrm{C}$ (Test\#1) and $360^{\circ} \mathrm{C}$ (Test\#2). This alloy is studied for a techno-economical optimization of a steam-PCM heat exchanger proposed in the thermal energy storage (TES) system of a direct steam generation (DSG) facility. The corrosion damage was analyzed with visual inspection, optical microscopy, SEM, EDS and XRD, and corrosion rates were also calculated. A387 Gr 91 alloy generates protective oxide layers over base metal. Localized corrosion damages were not detected with these test conditions, while XRD and EDS profiles showed $\mathrm{CrO}$ and $\mathrm{LiFeO}_{2}$ as main corrosion products generated by this alloy. On the other hand, corrosion rates decrease with exposure time showing the passivation of the alloy. A387 Gr 91 corrosion performance was compared with A316L stainless steel, which was preliminary proposed by the authors in previous studies. In addition to corrosion performance, parameters such as cost, thermal properties, and mechanical properties are discussed. In conclusion, the use of A387 Gr 91 instead to A316L alloy for the construction of the steam-PCM heat exchanger involves the techno-economical optimization of the equipment.
\end{abstract}

Keywords: Corrosion, phase change material (PCM), Cr-Mo alloys, hydroxides, thermal energy storage (TES) 


\section{Introduction}

Concentrating solar power (CSP) is called to play a critical role in solving the global climate challenge. Accordingly, this technology should contribute to the strategic energy policy objectives fixed for the different countries about reducing greenhouse emissions. CSP plants with thermal energy storage (TES) systems are unique renewable resources that provide not only clean electrical power, but also a range of operational capabilities that support continued reliability of electric power systems. TES systems allow providing the required amounts of power depending on grid operator demand regardless of the time of day or weather conditions. Therefore, CSP technologies with integrated TES systems have potential applications across a range of countries with different market structures and regulatory regimes [1-5]. TES systems based on phase change materials (PCM) is one of the most promising solutions for storing and releasing energy on demand in direct steam generation (DSG) CSP facilities. PCM systems can store/release a large amount of energy, the so-called latent heat, at constant temperature. Moreover, these solutions have larger energy density than systems working with sensible heat storage providing more compact storage systems for DSG power plants [6-8].

An optimized configuration based on molten salts tanks and PCM system has been proposed as TES module for DSG technology [9]. During periods without the solar source, sensible heat coming from molten salts is used for preheating and superheating the steam and latent heat is used for the evaporation process at constant temperature. While solar salt $\left(60 \% \mathrm{NaNO}_{3}-40 \% \mathrm{KNO}_{3}\right)$ is used in the sensible storage module, an optimized PCM is proposed by the authors for the latent storage one [10]. The PCM solution is a composite based in a $\mathrm{LiOH}-\mathrm{KOH}$ mixture (46wt.\% and $54 \mathrm{wt} . \%$, respectively) infiltrated in high conductive graphite foam. The carbon structure is characterized by high volumetric thermal conductivity, low density, highly interconnected porosity, and relatively high stiffness. The significant properties of the $\mathrm{LiOH} / \mathrm{KOH}$ mixture are: interesting melting point for DSG applications, large amount of energy involved in full crystallization/fusion ( $535 \mathrm{~kJ} / \mathrm{kg}$ as enthalpy change), fairly low relative volume expansion upon melting, and fairly low subcooling. Finally, the main advantages of the resulting composites are: very high energy density, relatively low volume expansion, highly enhanced heat transfer, thermo-adaptability, stability, and insignificant hysteresis.

Thermal transference between steam and proposed PCM takes place in a shell and tubes heat exchanger where steam flows through the tubes and hydroxides-graphite foam composite freezes and melts inside the shell during charge and discharge operation modes [11]. Heat exchanger materials selection is one of the main concerns for the design of this equipment. Then, the selected alloy should be corrosion resistant to high temperature hydroxides exposure to ensure an economic long-term design. The corrosion performance of three different alloy grades, carbon steel, stainless steel, and a nickel base alloy were evaluated by the authors in previous studies [12]. Accordingly, A316L austenitic stainless steel was preliminary selected as an interesting alloy for this application due to protective oxides layers generation and low corrosion rates. However, the high cost associated to this material motivates the evaluation of low cost alternatives to carry out a techno-economical optimization of the heat exchanger under discussion. Two main families, ferritic stainless steels and Cr-Mo steels are proposed, as materials with an intermediate cost between carbon steels and austenitic stainless steels, for the heat exchanger optimization.

Ferritic stainless steels consist of iron-chromium alloys with body-centered cubic crystal structures. These alloys are magnetic and not hardenable by heat treatment. Ferritic stainless steels have good ductility and formability but relatively poor high temperature strength compared to that of austenitic grades [13]. Due to their lower chromium and nickel content, standard ferritic steel grades are usually less expensive than their austenitic counterparts. Although 430 alloy is the general-purpose stainless steel of the ferritic group, slight chemical composition variations 
are proposed to improve properties such as weldability, corrosion resistant, among others (Figure 1.).

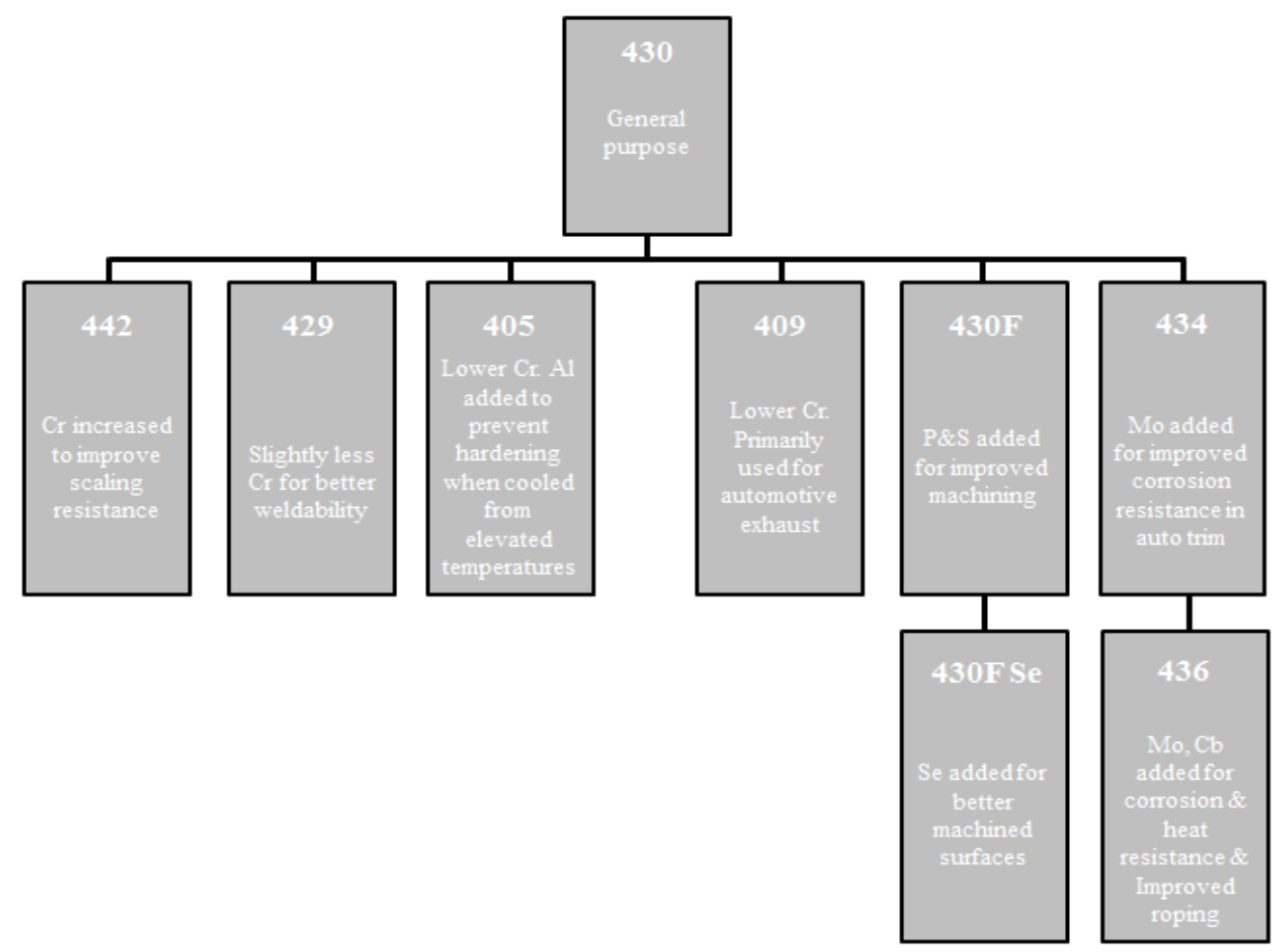

Figure 1. Some ferritic stainless steels grades. Chemical composition modification regarding AISI 430 [13]

On the other hand, chromium-molybdenum steels (A387 for plates and A335 for seamless pipes) are alloys intended for high temperature and pressure services. These types of steels are typically used in a variety of plants and processes worldwide, including refineries, power plants, and petrochemical plants among others, because of the high temperature strength, corrosion resistance and cost-effectiveness. Different grades of Cr-Mo alloys are available, mainly attending to the amount of these alloying elements and the presence of small traces of $\mathrm{V}, \mathrm{Nb}, \mathrm{N}, \mathrm{Al}$, among others [14$16]$.

Chemical compositions associated to some interesting grades are shown in Table 1 and Table 2 [17]. The main alloying element in typical ferritic stainless steels is chromium in the range of 10.5-18wt.\%. In addition to $\mathrm{Cr}, \mathrm{Si}$ and $\mathrm{Mn}$ are in the range of $1 \mathrm{wt} . \%$ and $\mathrm{P}$ and $\mathrm{S} 0.04 \mathrm{wt} . \%$ maximum. Some grades also include low percentages of $\mathrm{Ni}, \mathrm{Mo}, \mathrm{Al}, \mathrm{Ti}$, among other alloying elements. On the other hand, the main alloying elements in Cr-Mo alloys are $\mathrm{Cr}$ and $\mathrm{Mo}$ in the range of $1-9.50 \mathrm{wt} . \%$ and $0.45-1.10 \mathrm{wt} . \%$, respectively. $\mathrm{Si}$ is in the range of $0.2-1 \mathrm{wt} . \%$ and $\mathrm{Mn}$ is typically around $0.30-0.60 \mathrm{wt} . \%$. Moreover, the percentage of $\mathrm{P}$ and $\mathrm{S}$ is always lower than $0.035 \mathrm{wt} . \%$. Finally, grade 91 also includes a low amount of $\mathrm{Ni}, \mathrm{Nb}, \mathrm{V}, \mathrm{N}$ and $\mathrm{Al}$.

Table 1. Some Cr-Mo alloys grades. Chemical composition [17] 


\begin{tabular}{|c|c|c|c|c|c|c|c|c|}
\hline $\begin{array}{c}\text { Grade/Element } \\
(\text { wt.\%) }\end{array}$ & $\mathrm{C}$ & Mn & $\mathbf{P}$ & $\mathbf{S}$ & Si & $\mathrm{Cr}$ & Mo & Others \\
\hline Grade 11 & $\begin{array}{l}0.05- \\
0.17\end{array}$ & $\begin{array}{l}0.40- \\
0.65\end{array}$ & 0.035 & 0.035 & $\begin{array}{c}0.50- \\
0.80\end{array}$ & $\begin{array}{l}1.00- \\
1.50\end{array}$ & $\begin{array}{l}0.45- \\
0.65\end{array}$ & \\
\hline Grade 22 & $\begin{array}{l}0.05- \\
0.15\end{array}$ & $\begin{array}{c}0.30- \\
0.60\end{array}$ & 0.035 & 0.035 & 0.50 & $\begin{array}{c}2.00- \\
2.50\end{array}$ & $\begin{array}{c}0.90- \\
1.10\end{array}$ & \\
\hline Grade 5 & 0.15 & $\begin{array}{c}0.30- \\
0.60\end{array}$ & 0.035 & 0.030 & 0.50 & $\begin{array}{c}4.00- \\
6.00\end{array}$ & $\begin{array}{c}0.45- \\
0.65\end{array}$ & \\
\hline Grade 9 & 0.15 & $\begin{array}{c}0.30- \\
0.60\end{array}$ & 0.030 & 0.030 & 1.00 & $\begin{array}{l}8.00- \\
10.00\end{array}$ & $\begin{array}{c}0.90- \\
1.10\end{array}$ & \\
\hline Grade 91 & $\begin{array}{c}0.08- \\
0.12\end{array}$ & $\begin{array}{c}0.30- \\
0.60\end{array}$ & 0.020 & 0.010 & $\begin{array}{c}0.20- \\
0.50\end{array}$ & $\begin{array}{c}8.00- \\
9.50\end{array}$ & $\begin{array}{c}0.85- \\
1.05\end{array}$ & $\begin{array}{c}\text { Ni:0.40 } \\
\text { V:0.18-0.25 } \\
\text { Nb:0.06-0.10 } \\
\text { N: } 0.030-0.070 \\
\text { Al:0.04 }\end{array}$ \\
\hline
\end{tabular}

Table 2. Some ferritic stainless steels grades. Chemical composition [17]

\begin{tabular}{|c|c|c|c|c|c|c|c|c|c|c|}
\hline $\begin{array}{c}\text { Type/element } \\
\text { (wt.\%) }\end{array}$ & $\mathbf{C}$ & $\mathbf{M n}$ & $\mathbf{P}$ & $\mathbf{S}$ & $\mathbf{S i}$ & $\mathbf{C r}$ & $\mathbf{N i}$ & $\mathbf{M o}$ & $\mathbf{N}$ & Other \\
\hline 405 & 0.08 & 1.00 & 0.04 & 0.03 & 1.00 & $\begin{array}{c}11.50- \\
14.50\end{array}$ & 0.60 & & & Al: $0.10-0.30$ \\
\hline 409 & 0.030 & 1.00 & 0.04 & 0.01 & 1.00 & $\begin{array}{c}10.5- \\
11.7\end{array}$ & 0.50 & & 0.03 & $\begin{array}{c}\text { Ti: } 6 \mathrm{x}(\mathrm{C}+\mathrm{N}) \\
\text { min; } 0.50 \\
\text { max }\end{array}$ \\
\hline 429 & 0.12 & 1.00 & 0.04 & 0.03 & 1.00 & $\begin{array}{c}14.00- \\
16.00\end{array}$ & & & & \\
\hline 430 & 0.12 & 1.00 & 0.04 & 0.03 & 1.00 & $\begin{array}{c}16.00- \\
18.00\end{array}$ & 0.75 & & & \\
\hline 434 & 0.12 & 1.00 & 0.04 & 0.03 & 1.00 & $\begin{array}{c}16.00- \\
18.00\end{array}$ & & $0.75-$ & & \\
\hline
\end{tabular}


Mechanical properties, tensile strength and yield strength, are plotted in Figure 2 and Figure 3 for Cr-Mo alloys and ferritic stainless steels [17]. A316L austenitic stainless steel and A516 Gr 70 carbon steel are also included in these graphs in terms of comparison. While Cr-Mo alloys tensile strength are in the range of 515-690 MPa (Grade 11, 22, 5 and 9) and 585-760 MPa (Grade 91), ferritic stainless steels show lower values (380-450 MPa). Similar conclusion is extracted comparing yield strength, 310-415 MPa (Cr-Mo alloys) vs. 170-240 MPa (ferritic stainless steels). Accordingly, the better mechanical performance associated to Cr-Mo alloys would have a beneficial impact in the design of the heat exchanger tubes and shell.

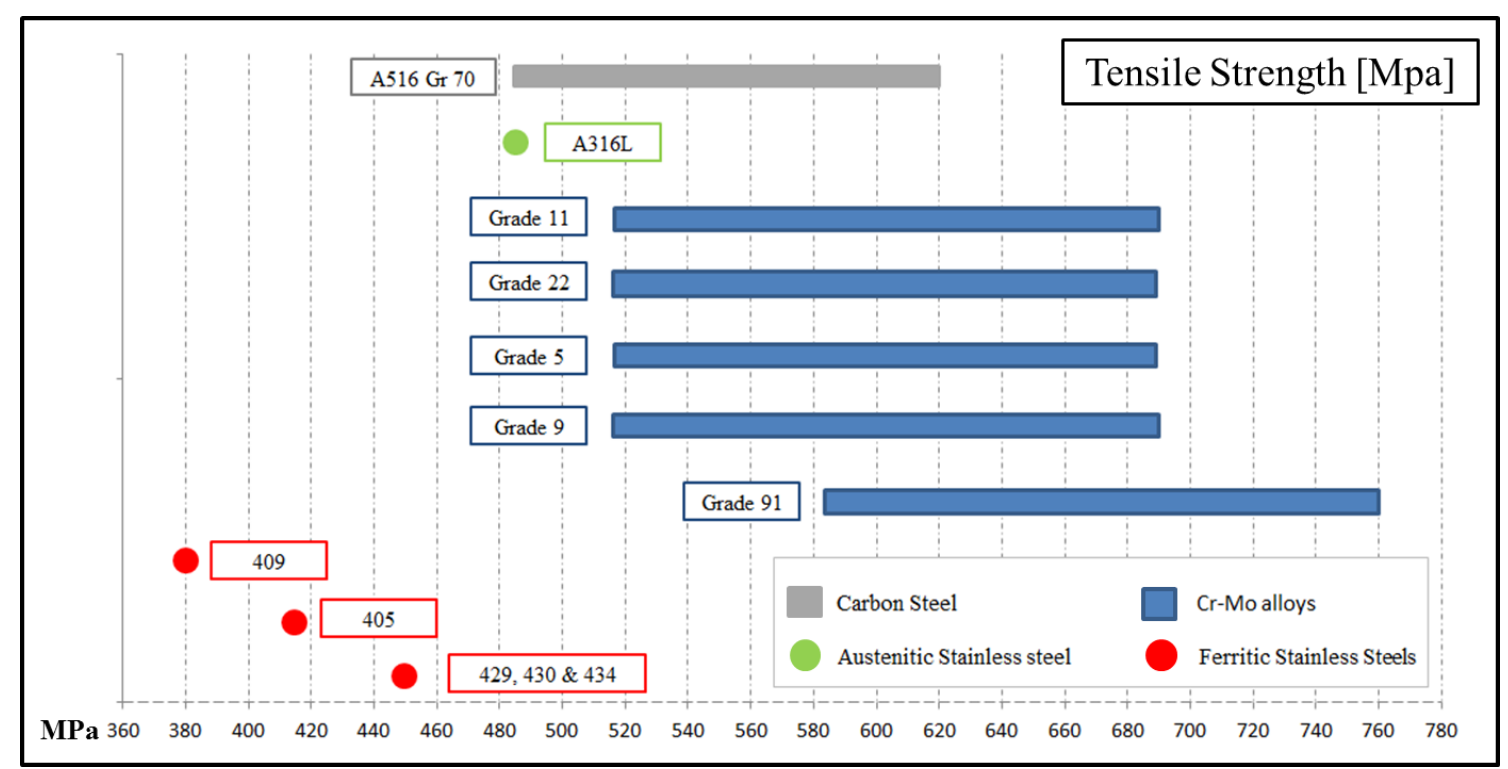

Figure 2. Tensile strength values comparison. Adapted from [17]

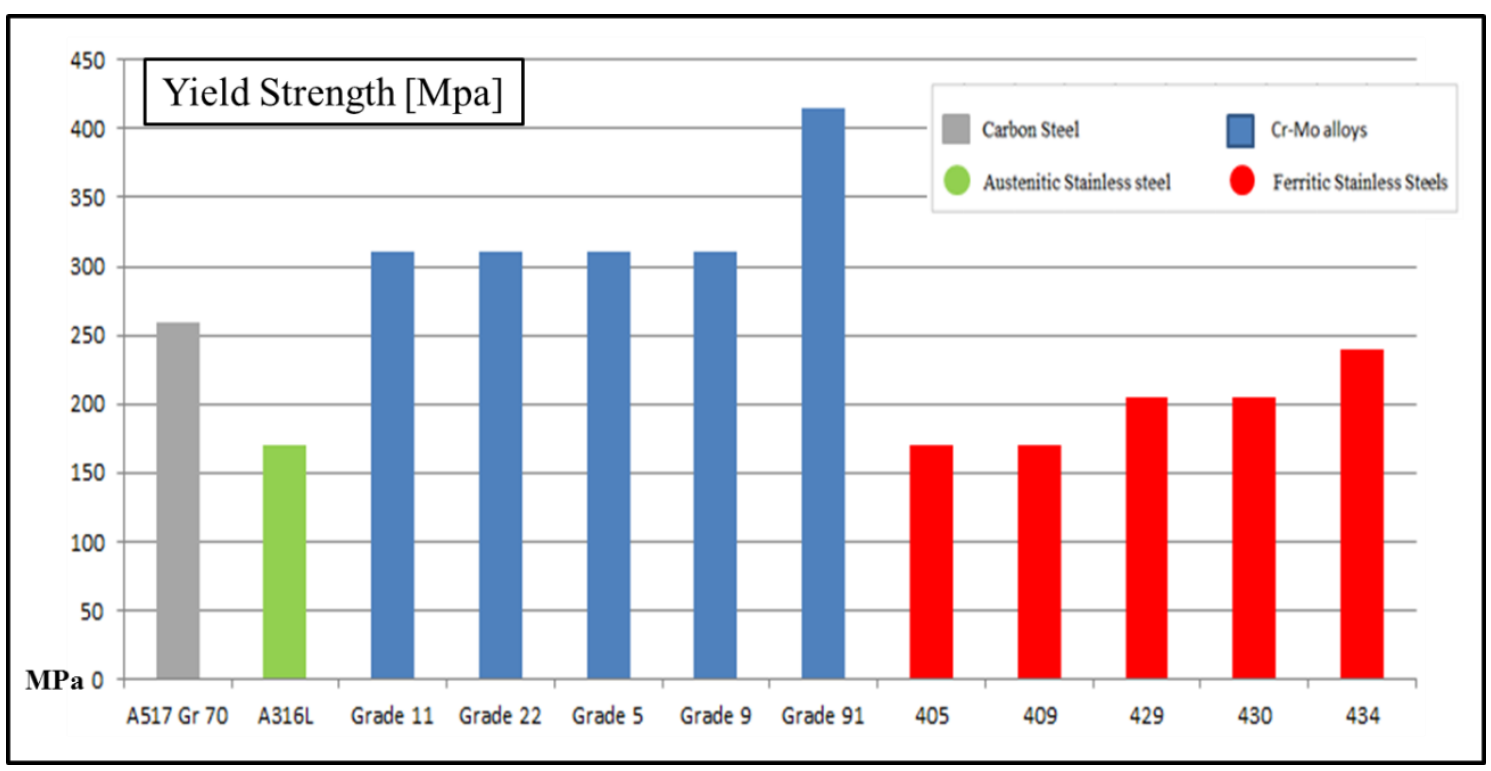

Figure 3. Yield strength values comparison. Adapted from [17] 
Attending to this discussion, Cr-Mo alloys have been selected by the authors for the technoeconomical optimization of the steam-PCM heat exchanger under evaluation. Within this family, a relative high content of $\mathrm{Cr}$ and $\mathrm{Mo}$ is desired to improve corrosion resistance taking into account poor performance showed by carbon steel (A516 Gr 70) after hydroxides exposition in previous studies [12]. Then, A387 Gr 91 has been chosen as the alloy to be tested in the hydroxides mixture because of three reasons. (i) Grade 91 shows the better mechanical performance within this family of alloys, (ii) the higher amount of $\mathrm{Cr}(8.00-9.50 \mathrm{wt} . \%)$ associated to this alloy improve the corrosion resistance of this material regarding Cr-Mo alloys with lower $\mathrm{Cr}$ content, and (iii) the presence of Mo in the range of $0.85-1.05 \mathrm{wt}$. \% is also beneficial from corrosion point of view.

\section{Materials and methods}

\subsection{PCM}

$\mathrm{LiOH}-\mathrm{KOH}$ mixture corrosion aggressiveness was evaluated to optimize the materials selection for the steam-PCM heat exchanger proposed for this application. The chemical composition for the $\mathrm{LiOH}-\mathrm{KOH}$ blend was $46 \mathrm{wt} . \% \mathrm{LiOH}$ and $54 \mathrm{wt} . \% \mathrm{KOH}$. A reversible peritectic reaction is associated with this mixture at temperature close to $315{ }^{\circ} \mathrm{C}$ (Reaction 1) $[18,19]$. The enthalpy change associated to the peritectic transition is $535 \mathrm{~kJ} / \mathrm{kg}$, becoming this mixture one of the most interesting PCM media for DSG technology from the point of view of energy density and melting point. Both hydroxides were supplied by Sigma Aldrich (Table 3).

$\mathrm{LiOH}-\mathrm{KOH}_{(\mathrm{Liq})}+\mathrm{LiOH}_{(\mathrm{S})} \leftrightarrow \mathrm{Li}_{2} \mathrm{~K}(\mathrm{OH})_{3}(\mathrm{~S})$

Table 3. LiOH, KOH characteristics [20]

\begin{tabular}{c|c|c|c|}
\hline \multicolumn{1}{c}{ LiOH } & KOH & \\
\hline Grade & Reagent grade & Puriss. p.a. & \\
\hline Purity & $98 \%$ & $\geq 86 \%$ & \\
\hline Salts supplied as & Pellets & Pellets & \\
\hline
\end{tabular}

\subsection{Metal alloy}

Previous studies carried out by the authors identified A316L stainless steel as preliminary material for the steam-PCM heat exchanger manufacturing [12]. After screening alternatives materials to A316L, A387 Gr 91 was identified as an interesting low cost alternative. A387 Gr 91 ferritic steel is a chromium-molybdenum alloy with excellent resistance to high working temperatures and good anti-corrosion characteristics. The small additions of $\mathrm{Nb}$ and $\mathrm{V}$ to the modified $9 \mathrm{Cr}-1 \mathrm{Mo}$ steel promote the formation of fine $(\mathrm{Nb}, \mathrm{V}) \mathrm{C}$ carbides and carbonitride particles evenly distributed throughout the matrix [16]. These precipitates explain the higher microstructural stability and the increase in material strength over long periods at a high temperature service. A387 Gr 91 has good weldability and with its heat resistant qualities, this alloy is a highly versatile steel, used in numerous applications [16]. Due to its performance in service in the power generation industry, the use of this alloy began in the early 90s worldwide in the petrochemical and crude oil refining 
industries, with a favorable combination of mechanical, physical and corrosion resistance properties compared to other ferritic steels such as $21 / 4 \mathrm{Cr}-1 \mathrm{Mo}$, $9 \mathrm{Cr}-1 \mathrm{Mo}$ and some austenitic steels up to $650^{\circ} \mathrm{C}$. The chemical composition of A387 Gr 91 is shown in Table 1 [17].

A387 Gr 91 microstructure was evaluated by optical microscopy (Motic BA210 trinocular compound microscope) before testing in the hydroxides bath at high temperature to analyze the microstructure and possible defects on reception (Figure 4). This preliminary characterization is also interesting to identify microstructure changes after hydroxides exposition. Thus, metallic sections were cut from alloy plates, embedded in resin and polished. A387 Gr 91 steel displayed a martensitic microstructure as expected for this alloy. Microstructure differences were not observed for this material between longitudinal and transversal directions to the rolling direction in the manufacturing process.

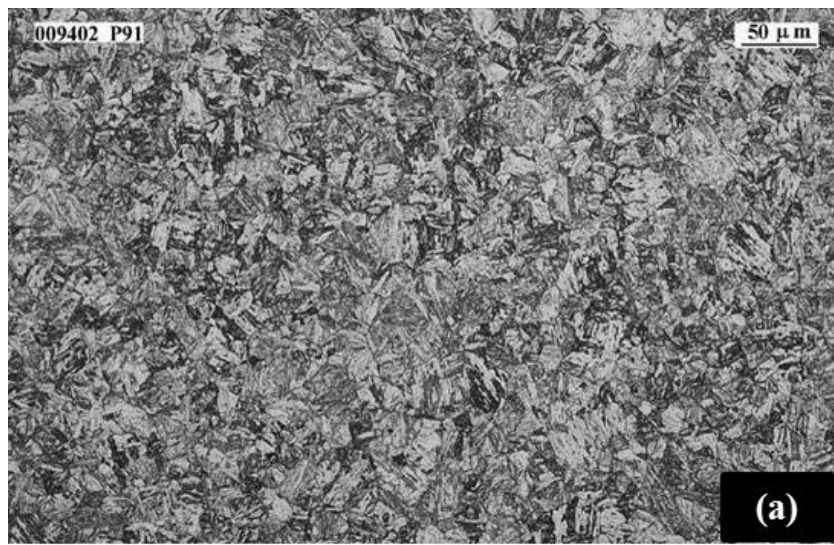

Figure 4. A387 Gr 91 microstructure before testing

\section{Methodology}

Two different corrosion tests were performed to analyze the corrosion performance of A387 Gr 91 alloy: (i) Conservative corrosion tests at $360{ }^{\circ} \mathrm{C}$ (Test \#1) to compare with $\mathrm{A} 316 \mathrm{~L}$ results obtained in previous studies, and (ii) Corrosion tests at $315^{\circ} \mathrm{C}$ (Test \#2), which is the peritectic temperature under evaluation.

Previously to corrosion tests, $\mathrm{LiOH}$ and $\mathrm{KOH}$ salts were heated up to $120^{\circ} \mathrm{C}$ to eliminate the expected water content associated to both hydroxides due to their hygroscopic behavior. Once water was completely removed, mixtures were prepared inside a glove box under an inert atmosphere. Corrosion tests were performed in several autoclaves where hydroxide mixtures were introduced and heated up to $360{ }^{\circ} \mathrm{C}$ and $315{ }^{\circ} \mathrm{C}$, respectively. After achieving the test temperatures, both autoclaves were opened and corrosion coupons were introduced inside. Two test times, 1005 hours $\left(\mathrm{t}_{1}\right)$ and 2640 hours $\left(\mathrm{t}_{2}\right)$, were executed for corrosion tests at $360{ }^{\circ} \mathrm{C}$ (Test\#1). On the other hand, corrosion test at $315^{\circ} \mathrm{C}$ (Test\#2) was performed during 1055 hours. While uniform corrosion coupons, welded coupons and SCC coupons were assembled to the corrosion rack for Test\#1, only uniform corrosion coupons were tested in Test\#2. In order to compare with previous results obtained for A316L , surface and cross section analysis, XRD and EDS profiles, and corrosion rates calculation were carried out for Test\#1 characterization. ASTM G1-03 standard was used to calculate materials corrosion rates after being exposed to hydroxides baths [21]. The descaled weight loss was evaluated for each coupon by removing oxides layers generated during the corrosion tests. ASTM G1-03 standard suggests different types of chemical solutions to remove corrosion products without attacking to base material. Accordingly, $50 \% \mathrm{HCl}$ solution plus $3.5 \mathrm{~g}$ hexamethylenetetramine was used for A387 Gr 91 oxides layer removal.

Eq. 1 was applied to obtain corrosion rates as $\mu \mathrm{m} /$ year: 


$$
V c=\frac{\Delta W}{S_{0}} \frac{K}{t \rho}
$$

where, $\Delta W$ is the weight after testing and removing corrosion products $(\mathrm{g}), S_{0}$ is the initial metallic surface in contact with hydroxides $\left(\mathrm{cm}^{2}\right), K$ is a constant to express the final result as $\mu \mathrm{m} /$ year $\left(8.76 \cdot 10^{7}\right), t$ is the exposure time in hours, and $\rho$ is the metallic alloy density in $\mathrm{g} / \mathrm{cm}^{3}$. It was assumed that the total weight loss was only associated to uniform corrosion without taking into account localized phenomena which were evaluated by other methods.

Surface and cross section microstructural characterization (spalling phenomena, oxides morphology, and corrosion damage penetration) was carried out over corrosion coupons by using a SEM-JEOL 5910-LV microscope. Energy dispersive spectroscopy (EDS) spectra were obtained from the material surface and the cross section to identify the alloying elements over the outermost oxides layers, and alloying elements evolution through corrosion products. EDS-OXFORD INCAX-act equipment coupled to SEM was used for oxides chemical characterization. In addition to EDS analysis, oxides layers were also chemically characterized by XRD (D8 advance Bruker) in order to identify the oxides layers stoichiometry. ASTM G30-97 and ASTM G58-85 standards were applied to analyze SCC susceptibility using U-bend corrosion coupons [22,23]. U-bend coupons are welded and bended at $180^{\circ} \mathrm{C}$ introducing permanent residual stresses coming from both processes. Taking into account that stresses induced in the coupons are higher than the elastic limit of the material, this test is the worst-case scenario regarding SCC susceptibility. Visual inspection and optical microscopy characterization (Motic BA210 trinocular compound microscope) was carried out to evaluate U-bend corrosion coupons after testing.

\section{Results and discussion}

\subsection{Test\#1. Conservative corrosion tests at $360{ }^{\circ} \mathrm{C}$}

A387 Gr 91 alloy was tested at $360^{\circ} \mathrm{C}$ in the $\mathrm{LiOH}-\mathrm{KOH}$ mixture during 1005 and 2640 hours. Corrosion test temperature was fixed at $360^{\circ} \mathrm{C}, 45^{\circ} \mathrm{C}$ above the hydroxide blend peritectic point, to calculate conservative corrosion rates for a safety and long-term design.

Corrosion racks were extracted from autoclaves after finishing test times at 1005 hours $\left(\mathrm{t}_{1}\right)$ and 2640 hours $\left(\mathrm{t}_{2}\right)$ (Figure 5). Hydroxides quickly solidified over corrosion coupons once racks were removed. Then, corrosion racks were cleaned in ultrasonic baths in order to remove hydroxides attached to the metallic structure and facilitate the extraction of the coupons for further characterization. 

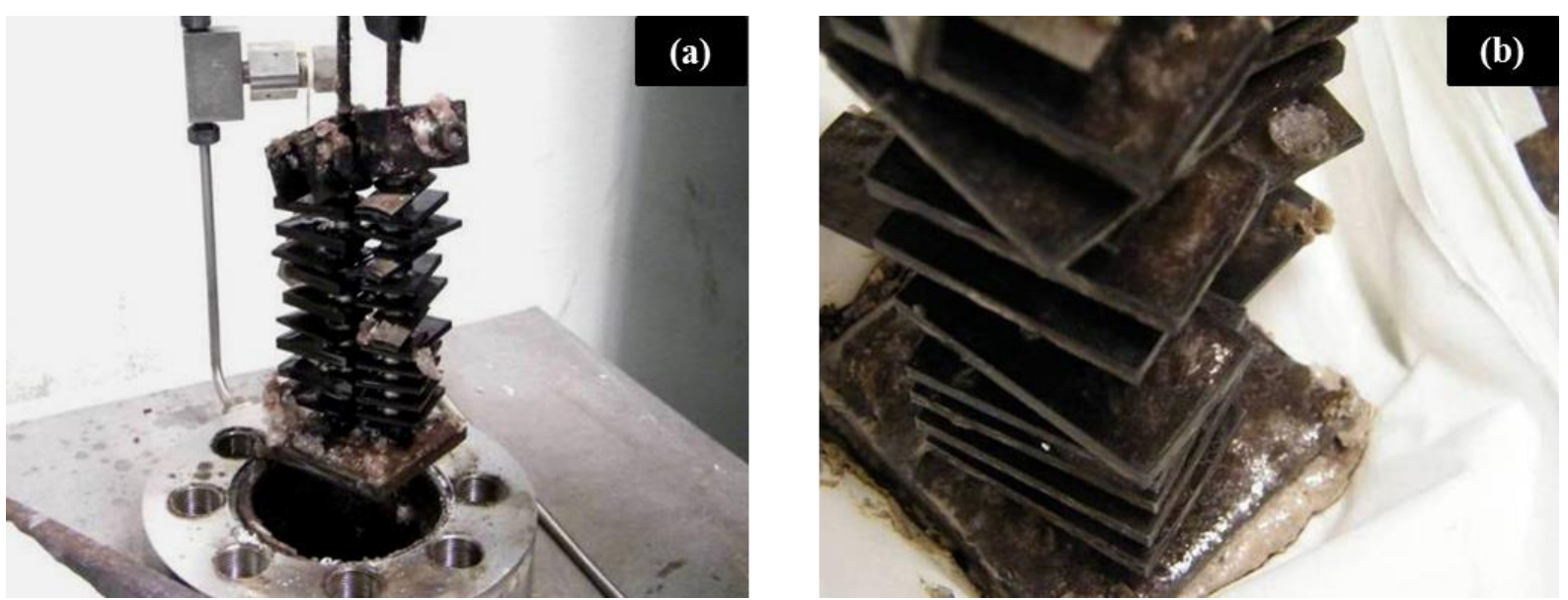

Figure 5. Corrosion rack removal from autoclaves: (a) Overall rack detail, (b) Corrosion coupons detail

\section{Visual inspection}

A387 Gr 91 showed very similar oxide aspect and shade for both test times, 1005 hours and 2640 hours. Coupons show uniform corrosion over base metal generating compact blackish-grey oxides layers well adhered to metal surface (Figure 6a). Accordingly, spalling phenomena were not detected and protective performance is foreseen. Localized damages such as pitting or other defects were not observed during visual inspection. Moreover, A387 Gr 91 welded coupon did not show preferential corrosion over the heat affected zone (HAZ), filler material or base metal (Figure 6b). Furthermore, cracking phenomena were not observed over A387 Gr 91 U-Bend coupons after hydroxides exposure (Figure 6c). These observations were verified by a detailed SEM examination.
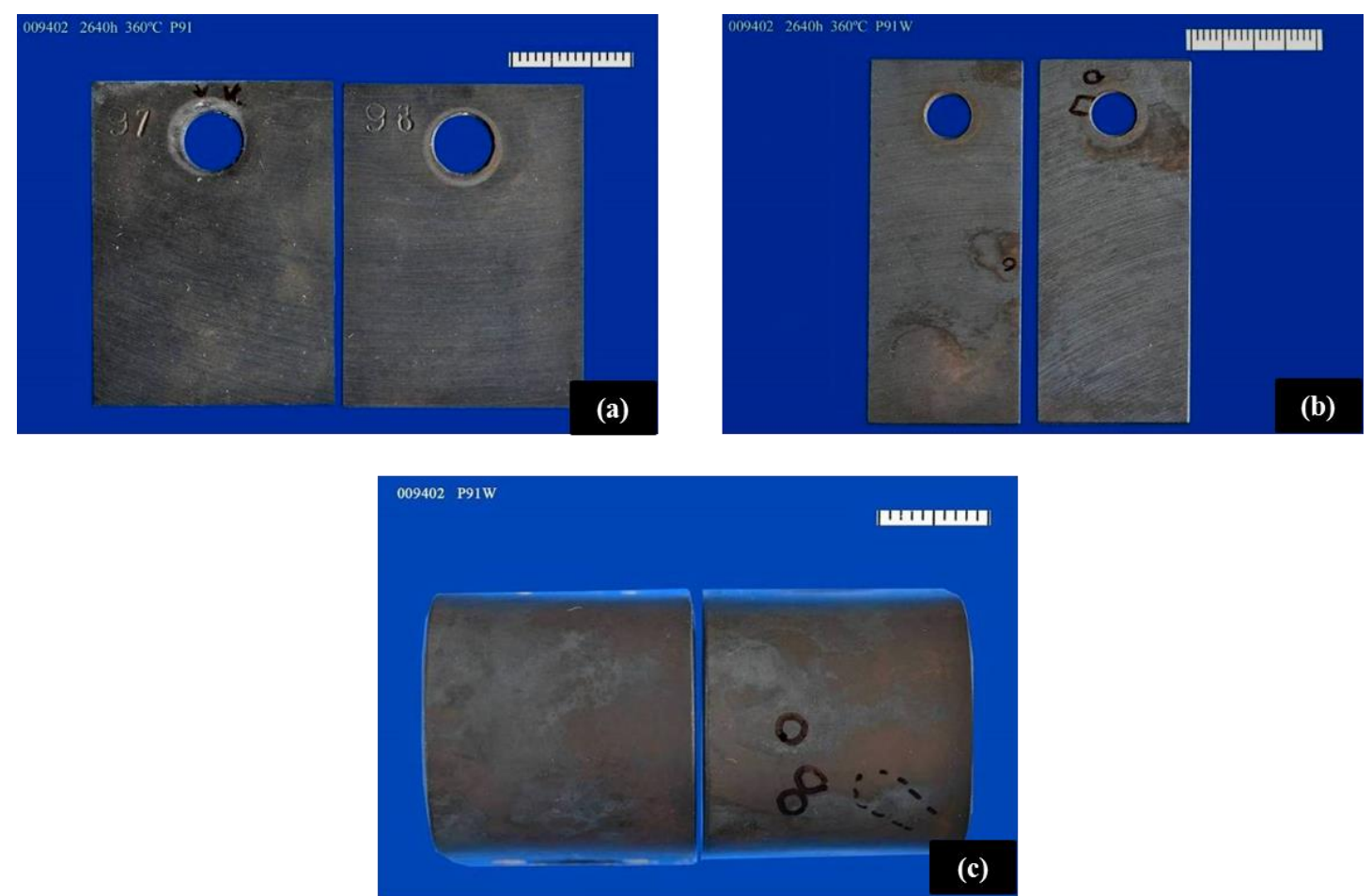
Figure 6. Corrosion coupons visual inspection: (a) A387 Gr 91 base coupons, (b) A387 Gr 91 welded coupons, (c) A387 Gr 91 SCC coupons

\section{Corrosion coupons surface analysis}

SEM characterization was carried out over coupons surface after corrosion tests. The oxide layer generated over A387 Gr91 coupons showed good substrate adhesion for both test times $\left(t_{1}\right.$, Figure $7 \mathrm{a}$ and Figure $7 \mathrm{~b} \mathrm{t}_{2}$, Figure $7 \mathrm{c}$ ). Moreover, coupons surface even maintained the original machining marks. EDS analysis carried out in the outer surface of the oxide layer indicates that corrosion deposits mainly consist on iron (Fe), Chromium $(\mathrm{Cr})$ and Oxygen $(\mathrm{O})$ (Figure 7d). Then, chromium and iron oxides are expected attending to EDS profile being the oxides stoichiometry identified by XRD.

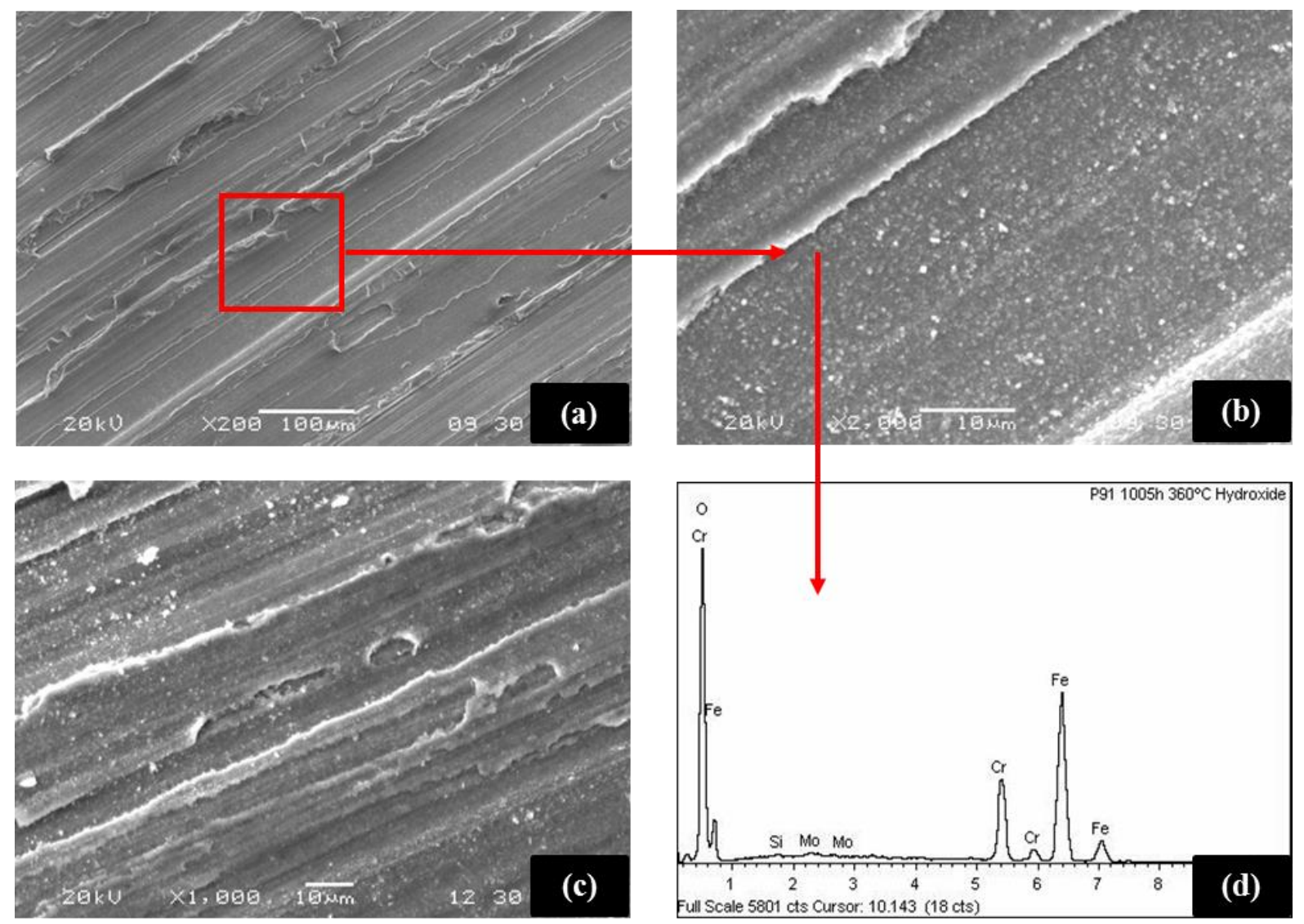

Figure 7. A387 Gr 91 SEM surface micrographs: (a) Coupon after $t_{1}$ test time (1005 hours, $x$ 200), (b) Coupon after $t_{1}$ test time (1005 hours, $\left.x 2000\right)$, (c) Coupon after $t_{2}$ test time (2640 hours, $x 1000)$, (d) EDS spectra associated to coupon after $t_{1}$ test time (1005 hours)

\section{Corrosion coupons transversal section analysis}

Metallographic specimens were machined from A387 Gr91 coupons after finishing corrosion tests in the hydroxides mixtures. Specimens were analyzed by SEM and EDS mapping to analyze oxides morphology and corrosion attack progression through the base material. In addition to SEM and EDS characterization, XRD analysis was performed to identify the oxide layer stoichiometry.

Cross-section SEM micrograph is shown in Figure 8 after $t_{1}$ test time (1005 hours). An adherent and homogeneous layer is observed with a constant thickness in the range of 8.5 microns (Figure 
8a). The compositional profile through oxide layer shows the corrosion products mainly composed by iron $(\mathrm{Fe})$ and Chromium $(\mathrm{Cr})$ (Figure 8a). XRD spectrum identifies oxides generated over base metal as $\mathrm{CrO}$ and $\mathrm{LiFeO}_{2}$ (Figure $8 \mathrm{~b}$ ). Taking into account that the ionic radius of lithium ion is $0.68 \AA$, lithium ion is easily incorporated into the crystal lattices of iron oxides to form $\mathrm{LiFeO}_{2}$, and $\mathrm{LiFe}_{5} \mathrm{O}_{8}$ as reported in the literature [24]. The formation of lithium ferrate has been identified as a protective and passive oxide layer $[25,26]$. Some interesting characteristics associated to lithium ferrate regarding corrosion inhibition and protection are: (i) $\mathrm{LiFeO}_{2}$ is insoluble in water, (ii) has a ceramics-like structure, and (iii) shows a high diffusion resistance to the migration of hydrogen, oxygen, iron and other atoms. Then, the formation of $\mathrm{LiFeO}_{2}$ could be considered as beneficial in terms of corrosion to assure a long-term corrosion performance of the alloy exposed to hydroxides mixture. Finally, the oxide layer generated after 2640 hours ( $t_{2}$ test time) was also adherent and compact being the thickness of the corrosion products in the range of 10-12 microns (Figure 8c).
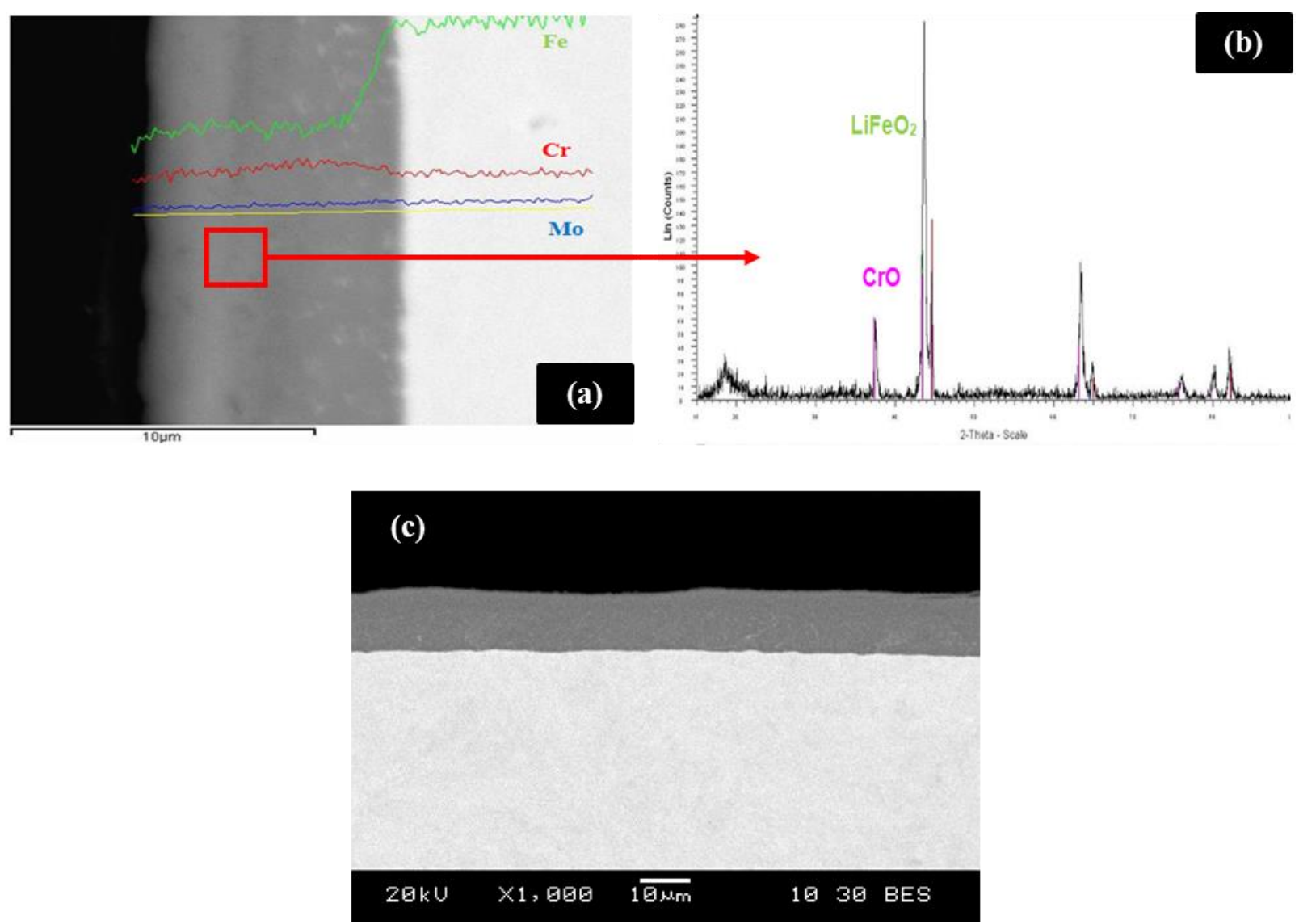

Figure 8. A387 Gr 91 SEM cross section micrographs: (a) SEM micrograph and EDS profile ( $t_{1}$ test time, 1005 hours), (b) XRD spectrum ( $t_{1}$ test time), (c) SEM micrograph ( $t_{2}$ test time, 2640 hours)

\section{Stress corrosion cracking (SCC) evaluation}

In addition to visual inspection over A387 Gr 91 SCC coupons, optical microscopy was performed to analyze more in detail the SCC sensitivity of this alloy under hydroxides exposure. This section (Figure 9) reveals a pore produced in the welding process during the SCC coupon manufacturing. Cracks are not detected in the welding area even in the neighboring zone of the pore, which acts as a stress concentration region. Then, the combination alloy induced residual stresses due to 
bending and welding processes, hydroxide mixture and operation condition simulated within Test\#1 were not aggressive enough to produce cracking and catastrophic failures in the bending area of the U-bend coupon. In conclusion, A387 Gr 91 would not be affected by SCC phenomena under test conditions.

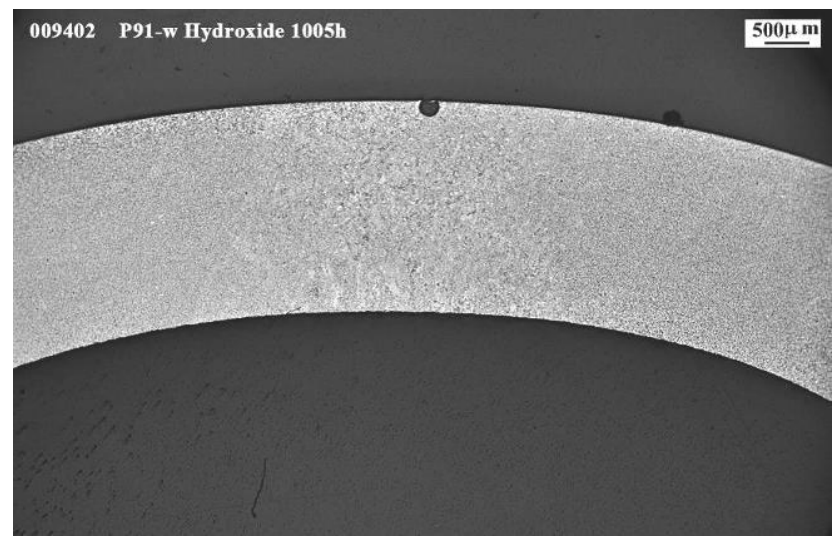

Figure 9. A387 Gr 91 SCC coupon section

\section{Corrosion rates calculation}

Once oxide layers morphology and composition, corrosion damage penetration and SCC sensitivity were characterized, corrosion rates calculation was performed by following ASTM G1-03 guidelines. Corrosion rates as $\mu \mathrm{m} /$ year were quantified for both test times under evaluation for Test\#1 (1005 hours and 2640 hours). The guide for corrosion weight loss used in the industry has been applied within this study to identify the expected performance of A387 Gr 91 and compare with previous results obtained for A316L [27]. A387 Gr 91 corrosion rates decrease from $55.9 \mu \mathrm{m} /$ year after 1005 hours hydroxides exposure down to $44.7 \mu \mathrm{m} /$ year after 2640 hours.

Accordingly, corrosion rates decreasing show a protective performance of the oxides layers generated over the base metal as expected after the microstructural characterization. Taking into account oxides morphology and corrosion rates evolution, parabolic or logarithmic kinetic corrosion is expected for this material. Then, corrosion products produce the passivation of the alloy minimizing the diffusion of anions and cations through the oxides layers.

Attending to the guide for corrosion weight loss, caution recommended depending on the specific application is advised for A387 Gr 91. However, corrosion rates decreasing through exposure time and protective oxide layer generation would allow a reliable design in terms of corrosion for the construction of the heat exchanger.

Previous tests carried out over A316L under same test conditions showed lower corrosion rates. Corrosion rates also decreased through test time from $10.3 \mu \mathrm{m} /$ year to $6.3 \mu \mathrm{m} /$ year after 1005 hours and 2640 hours, respectively [12].

Table 4. Corrosion rates for A387 Gr 91 after Test\#1

\begin{tabular}{|c|c|c|}
\hline Alloy & $\begin{array}{c}\text { Corrosion rate }(\mu \mathrm{m} / \text { year }) \\
\text { after } \mathrm{t}_{1} \text { test time }(1005 \text { hours })\end{array}$ & $\begin{array}{c}\text { Corrosion rate }(\mu \mathrm{m} / \text { year }) \\
\text { after } \mathrm{t}_{2} \text { test time }(2640 \text { hours })\end{array}$ \\
\hline A387 Gr 91 & $55.9 \pm 0.6$ & $44.7 \pm 0.1$ \\
\hline
\end{tabular}


Table 5. Guide for corrosion rates in the industry adapted to A387 Gr 91 [27]

\begin{tabular}{|c|l|}
\hline A387 Gr 91 $(\boldsymbol{\mu m} /$ year $)$ & \multicolumn{1}{|c|}{ Recommendation } \\
\hline $\mathbf{1 2 7 8}$ & Completely destroyed within days \\
\hline $\mathbf{1 2 9}-\mathbf{6 4}-\mathbf{1 2 8}$ & Not recommended for service greater than a month \\
\hline $\mathbf{1 4} \mathbf{- 6 3}$ & Not recommended for service greater than 1 year \\
\hline $\mathbf{0 . 4}-\mathbf{1 3}$ & Caution recommended, based on the specific application \\
\hline$<\mathbf{0 . 3}$ & Recommended for long term service \\
\hline & $\begin{array}{l}\text { Recommended for long term service; no corrosion, other than as a result of } \\
\text { surface cleaning, was evidenced }\end{array}$ \\
\hline
\end{tabular}

\subsection{Test\#2. Corrosion tests at $315^{\circ} \mathrm{C}$}

Low corrosion allowances are critical in the design of the steam-PCM heat exchanger due to: (i) heat transfer optimization between PCM and steam, and (ii) heat exchanger cost reduction. Therefore, an additional corrosion test at hydroxide mixtures melting point temperature $\left(315^{\circ} \mathrm{C}\right)$ was carried out for the $\mathrm{A} 387 \mathrm{Gr} 91$ alloy. This new corrosion test was also motivated taking into account that results coming from the conservative corrosion tests at $360{ }^{\circ} \mathrm{C}$ were satisfactory in terms of corrosion products morphology and expected corrosion kinetics. Then, A387 Gr 91 corrosion coupons were tested in the hydroxides bath during 1055 hours.

\section{Visual inspection and microscopic analysis}

Corrosion coupons also showed uniform corrosion with a well adhered and compact blackish oxide layer over base metal (Figure 10a). Corrosion extension seems to be lower than obtained in Test\#1 due to machining marks were more easily detected (Figure 10b). This observation was confirmed after SEM analysis (Figure 10c). Accordingly, a very superficial oxidation is showed in the micrograph with some areas where even lack of corrosion products is detected. 

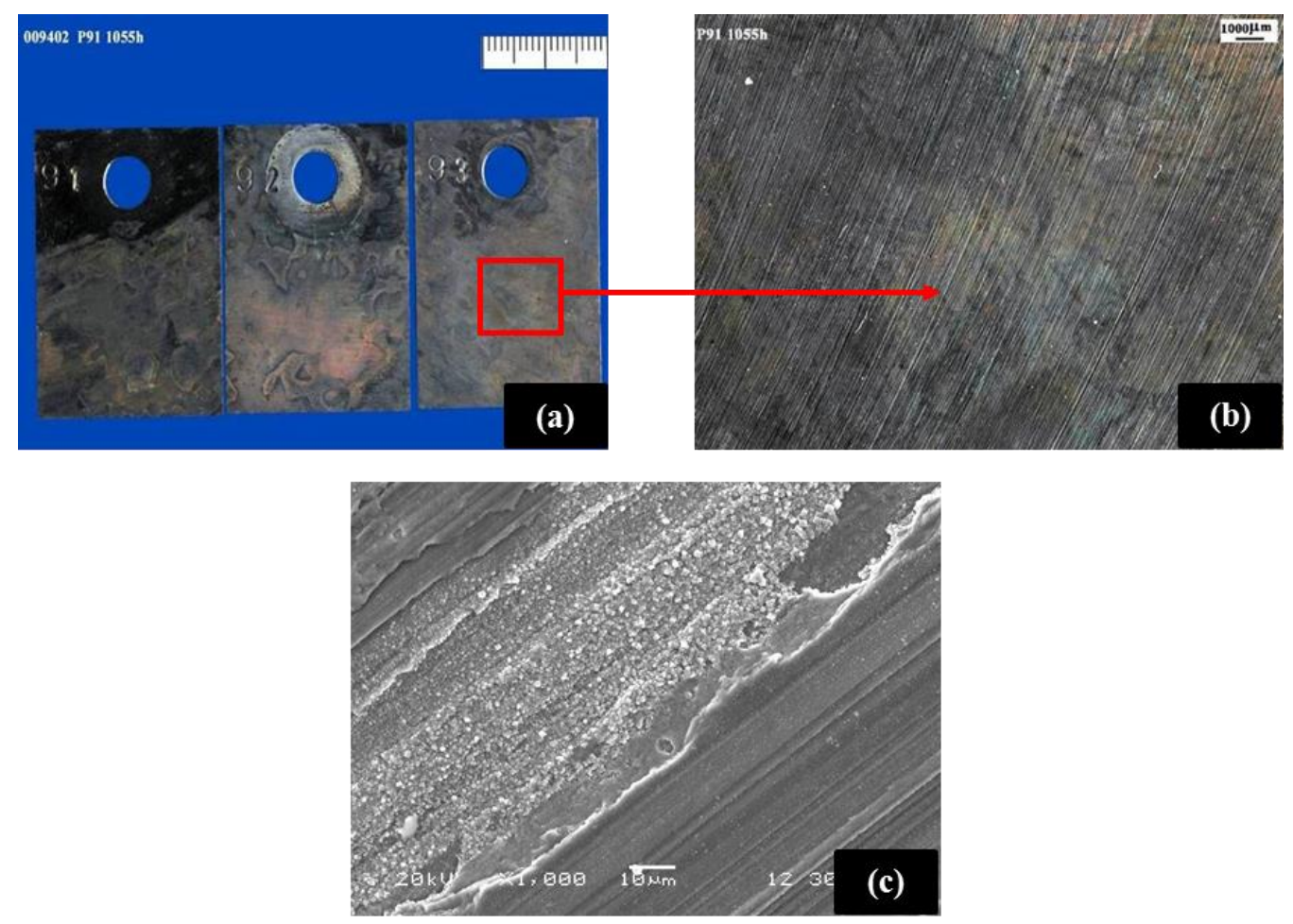

Figure 10. A387 Gr 91 visual and SEM inspection: (a) Corrosion coupons status after Test\#2 exposure, (b) Corrosion coupon surface detail, (c) SEM micrograph

\section{Corrosion rates calculation}

Once low corrosion damage was detected after visual and microscopic evaluation, corrosion rates were calculated to confirm a better corrosion performance regarding coupons evaluated in Test\#1. Oxides layer removal was performed after 1055 hours hydroxides exposure following same procedure described in previous sections. Descaled weight loss shows $29.6 \mu \mathrm{m} /$ year corrosion rate which means more than 50\% reduction regarding the one measured in Test\#1 after 1005 hours thermal-corrosive treatment. Therefore, quantitative values confirm a corrosion performance optimization for $\mathrm{A} 387 \mathrm{Gr} 91$ at $315^{\circ} \mathrm{C}$.

Alloy passivation through exposure time was detected for corrosion coupons at $360^{\circ} \mathrm{C}$ in Test\#1. Therefore, similar performance is expected for exposure at $315^{\circ} \mathrm{C}$ once confirmed that the hydroxides mixture at this temperature is a less aggressive environment for the alloy under revaluation. Although "Caution recommended, based on the specific application" is also advised, parabolic or logarithmic corrosion kinetic is awaited for A387 Gr 91 alloys. Then, corrosion rate decreasing is expected for long-term expositions being this alloy a potential candidate for the construction of the heat exchanger under evaluation.

Table 6. Corrosion rates for A387 Gr 91 after Test\#2

\begin{tabular}{|c|c|}
\hline Alloy & Corrosion rate $(\mu \mathrm{m} / \mathrm{year})$ after 1055 hours \\
\hline A387 Gr 91 & $29.6 \pm 0.2$ \\
\hline
\end{tabular}




\subsection{A387 Gr 91 and A316L alloys comparison}

In addition to corrosion performance, parameters involved in the efficiency and cost of the steamPCM heat exchanger such as material cost, thermal properties and mechanical properties are discussed within this section.

Although both materials generate protective, compact and well-adhered oxides layers over base metal, A316L corrosion rates are lower than the one measured in A387 Gr 91. While A387 Gr 91 corrosion rates are $55.9 \mu \mathrm{m} /$ year and $44.7 \mu \mathrm{m} /$ year for 1005 hours and 2640 hours, respectively, A316L exhibits $10.3 \mu \mathrm{m} /$ year and $6.3 \mu \mathrm{m} /$ year for the same test times [12]. On the other hand, previous studies carried out with $\mathrm{A} 316 \mathrm{~L}$ showed a slight corrosion progression through grain boundaries. Although IGC attack was just limited to $10 \mu \mathrm{m}$ depth, this corrosion damage could be a handicap to ensure long term design [12].

Alloy thermal conductivity is an important property affecting to the overall heat transfer of the heat exchanger proposed for this application. According to Table 7, where values for different temperatures are collected for both materials [28], A387 Gr 91 has higher thermal conductivity than A316L. In fact, the thermal conductivity ratio A387 Gr 91-A316L at heat exchanger operation temperature, $315^{\circ} \mathrm{C}$, is $1.5 \mathrm{x}$.

Table 7. A387 Gr 91 and A316L thermal conductivity comparison [28]

\begin{tabular}{|l|c|c|c|c|c|c|c|c|}
\hline Temperature $\left({ }^{\circ} \mathbf{C}\right)$ & 38 & 93 & 149 & 204 & 260 & 316 & 371 & 399 \\
\hline A387 Gr 91 thermal conductivity $(\mathrm{W} / \mathrm{m} \cdot \mathrm{K})$ & 22.7 & 24.2 & 25.4 & 26.3 & 27.0 & 27.5 & 27.7 & 27.8 \\
\hline A316 thermal conductivity $(\mathrm{W} / \mathrm{m} \cdot \mathrm{K})$ & 14.4 & 15.2 & 16.1 & 16.9 & 17.6 & 18.5 & 19.4 & 19.7 \\
\hline
\end{tabular}

In addition to thermal properties, the alloy cost is an important benefit associated to A387 Gr 91 to be considered as a potential candidate for the construction of the heat exchanger. While A316L main alloying elements are chromium, nickel and molybdenum in the range of 16-18wt.\%, 10$14 \mathrm{wt} . \%$ and 2-3wt.\%, respectively, A387 Gr 91 contains the same main alloying elements, 8$9.5 \mathrm{wt} . \%$ chromium, $0.4 \mathrm{wt} . \%$ nickel and $0.85-1.05 \mathrm{wt} . \%$ molybdenum. The lower amount of $\mathrm{Cr}$ and $\mathrm{Ni}$ is a determining factor for the final cost of A387 Gr 91 alloy.

Finally, mechanical properties of A387 Gr 91 are an additional advantage for the construction of the proposed heat exchanger. The construction of the equipment would be carried out following ASME Section VIII, boiler and pressure vessel code, where requirements applicable to the design, fabrication, inspection, testing, and certification of pressure vessels are specified [29]. This standard provides equations for the design of the shell and the tubes of the heat exchanger. Then, parameters such as geometrical requirements, temperature and pressure design, corrosion allowance, and mechanical properties of the materials under consideration are involved in the design of these elements.

Attending to ASME Section II (Materials Part A - ferrous materials specification), maximum design temperature for A387 Gr 91 and A316L under ASME VIII standard is $649{ }^{\circ} \mathrm{C}$ and $454{ }^{\circ} \mathrm{C}$, respectively [17]. Maximum allowable stresses between $65^{\circ} \mathrm{C}$ and $450{ }^{\circ} \mathrm{C}$ for both materials are shown in Table 8 [17]. A387 Gr 91 shows higher maximum allowable stress, which means a thickness reduction for the construction of the heat exchanger shell and tubes. As an example of size optimization using A387 Gr 91, tubes thicknesses are calculated by the following equation (Eq. 2): 
where $\mathrm{t}$ is the minimum required thickness of the tube $(\mathrm{mm}), \mathrm{P}$ is the internal design pressure $(\mathrm{MPa}), \mathrm{R}$ is the corroded inside radius of the tube under design $(\mathrm{mm}), \mathrm{S}$ is the maximum allowable stress value (MPa), E is the joint efficiency (-), and CA is the additional thickness for corrosion allowance $(\mathrm{mm})$. Parameters involved in the thickness calculation for a 20 years design are provided in Table 9. Design temperature and pressure has been fixed at $350{ }^{\circ} \mathrm{C}$ and 121 bar, respectively. Joint efficiency has been considered as 1. Regarding maximum allowable stress, 161 $\mathrm{MPa}$ and $94.1 \mathrm{MPa}$ have been taken for A387 Gr 91 and A316L, respectively.

The corrosion allowance for A387 Gr 91 takes into account the corrosion coming from hydroxides at $315{ }^{\circ} \mathrm{C}$ and corrosion due to steam. On the other hand, only corrosion due to steam has been considered for A316L assuming no corrosion in the hydroxides side. The consideration of no hydroxides corrosion in A316L has been adopted to compare final tubes thicknesses in the bestcase scenario for A316L (A316L immune to hydroxides corrosion). On the other hand, although negligible corrosion is expected in the steam side for both materials, $0.2 \mathrm{~mm}$ corrosion allowance has been considered as a conservative value [30]. Finally, $20 \mathrm{~mm}$ has been assumed for the inside radius (not corroded).

Results show lower tubes thickness for A387 Gr 91, $2.86 \mathrm{~mm}$ versus $3.89 \mathrm{~mm}$ for tubes manufactured in A316L. As explained before, the lower maximum allowable stress associated to A316L increase the tubes thickness for this material. Accordingly, even taking into account no corrosion for A316L in the hydroxides side, the heat exchanger tubes thickness would be thicker for this material. Then, A387 Gr 91 thermo-mechanical properties cover a higher corrosion allowance requirement.

Table 8. MAS for A387 Gr 91 and A316L [17]

\begin{tabular}{|l|c|c|c|c|c|c|c|c|}
\hline Temperature $\left({ }^{\circ} \mathrm{C}\right)$ & 65 & 125 & 200 & 300 & 325 & 350 & 400 & 450 \\
\hline A387 Gr 91 MAS (MPa) & 168 & 168 & 167 & 164 & 163 & 161 & 153 & 141 \\
\hline A316L MAS (MPa) & 115 & 115 & 109 & 98 & 95.7 & 94.1 & 90.9 & 87.8 \\
\hline
\end{tabular}

Table 9. Parameter involved in tubes thickness calculation

\begin{tabular}{|c|l|l|l|l|l|l|l|}
\hline $\begin{array}{l}\text { Design } \\
\text { Pressure } \\
(\mathrm{MPa})\end{array}$ & $\begin{array}{l}\text { Design } \\
\text { Temperature } \\
\left({ }^{\circ} \mathrm{C}\right)\end{array}$ & $\begin{array}{l}\text { Inside } \\
\text { Radius } \\
(\mathrm{mm})\end{array}$ & $\begin{array}{l}\text { Joint } \\
\text { Efficiency } \\
(-)\end{array}$ & $\begin{array}{l}\text { Maximum } \\
\text { allowable } \\
\text { stress(MPa) }\end{array}$ & \multicolumn{3}{|l|}{$\begin{array}{l}\text { Corrosion } \\
\text { allowance (mm) }\end{array}$} \\
\cline { 4 - 8 } & & & $\begin{array}{l}\text { A387 Gr } \\
91\end{array}$ & A316L & $\begin{array}{l}\text { A387 } \\
\text { Gr 91 }\end{array}$ & A316L \\
\hline 121 & 350 & 20 & 1 & 161 & 94.1 & 0.792 & 0.2 \\
\hline
\end{tabular}

In conclusion, A387 Gr 91 is a more promising alloy for the manufacturing of the steam-PCM heat exchanger than A316L alloy. Although corrosion rates obtained for A387 Gr 91 are higher, passivation of the alloy has been demonstrated and good long-term corrosion performance is 
expected. Moreover, intergranular attack has not been detected for A387 Gr 91, which is one of the main drawbacks found for A316L. On the other hand, properties such as thermal conductivity, maximum allowable stress, and cost of the alloy make this material a better candidate for this application than A316L.

\section{Conclusions}

Corrosion performance of $\mathrm{A} 387 \mathrm{Gr} 91$ alloy exposed to a peritectic mixture of $\mathrm{LiOH}$ and $\mathrm{KOH}$ was studied for the construction of a steam-PCM heat exchanger. In addition to corrosion rates calculation, the corrosion damage of this allow was characterized by several techniques. A387 Gr 91 corrosion performance has been compared with A316L alloy, which was selected by the authors as preliminary candidate for the manufacturing of the heat exchanger in previous tests. Two different tests were performed: (i) Test\#1 at $360{ }^{\circ} \mathrm{C}$, a conservative corrosion test $45{ }^{\circ} \mathrm{C}$ above the operation temperature of the heat exchanger, to compare with previous results obtained for $\mathrm{A} 316 \mathrm{~L}$, and (ii) Test $\# 2$ at $315^{\circ} \mathrm{C}$, the $\mathrm{LiOH}-\mathrm{KOH}$ mixture peritectic point.

During Test\#1 (360 ${ }^{\circ} \mathrm{C}$ exposition), A387 Gr 91 alloy generates compact protective oxide layers which were good adhered to the base metal. Localized corrosion damages such as pitting, intergranular corrosion, or spalling phenomena were not detected under these test conditions. XRD and EDS profiles showed $\mathrm{CrO}$ and $\mathrm{LiFeO}_{2}$ as main corrosion products generated by this alloy. $\mathrm{LiFeO}_{2}$ oxide layer would act as a diffusion barrier reducing the corrosion process. This observation was confirmed once calculated the corrosion rates. Corrosion rates decrease with exposure time showing the passivation of the alloy. These results were compared with previous test on A316L alloy under same test conditions. A316L showed lower corrosion rates; 10.3 $\mu \mathrm{m} /$ year vs. $55.9 \mu \mathrm{m} /$ year ( $\mathrm{t}_{1}$ test time, 1005 hours) and $6.3 \mu \mathrm{m} /$ year vs. $44.7 \mu \mathrm{m} /$ year $\left(\mathrm{t}_{2}\right.$ test time 2640 hours). Although A316L also showed protective oxides layer generation, slight intergranular corrosion was detected. This localized corrosion damage has been identified as the main handicap for a long-term design using A316L for the manufacturing of the heat exchanger. Test $\# 2\left(315^{\circ} \mathrm{C}\right.$ exposition) was motivated due to good corrosion performance exhibited by A387 Gr 91 alloy after tests at $360{ }^{\circ} \mathrm{C}$. Visual inspection and SEM analysis showed lower corrosion damage compared to Test\#1. This observation was confirmed with corrosion rates calculation obtaining corrosion damage in the range of $29 \mu \mathrm{m} /$ year after 1055 hours.

In addition to corrosion performance, other parameters such as cost, thermal properties, and mechanical properties have been discussed within this study. A387 gr 91 cost is lower than A316L ones due to the lower content of Ni, Cr, and Mo. Moreover, A387 Gr 91 thermal conductivity is higher, which is a key point for the thermal transference between the PCM and steam. On the other hand, A387 Gr 91 maximum allowable stress is also significantly higher. The better mechanical performance has a direct impact on the sizing of the equipment reducing the thickness required for the temperature and pressure combination.

In conclusion, the use of A387 Gr 91 instead to A316L alloy for the construction of the steamPCM heat exchanger involves the techno-economical optimization of the equipment.

\section{Acknowledgements}

The research leading to these results has received funding from CDTI in the project Innterconecta Thesto (ITC-20111050). The work is partially funded by the Spanish government (ENE201564117-C5-1-R, and ENE2015-64117-C5-2-R). The authors would like to thank the Catalan 
Government for the quality accreditation given to their research group GREA (2014 SGR 123) and research group DIOPMA (2014 SGR 1543). The research leading to these results has received funding from the European Union's Horizon 2020 research and innovation programme under grant agreement No 657466 (INPATH-TES).

\section{References}

[1] Cabeza L, Galindo E, Prieto C, Barreneche C, Fernández, A. Key performance indicators in thermal energy storage: Survey and assessment, 2015; 83: 820-827

[2] Gil A, Medrano M, Martorell I, Lázaro A, Dolado P, Zalba B, Cabeza L. State of the art on high temperature thermal energy storage for power generation. Part 1 - Concepts, materials and modelization. Renewable and Sustainable Energy Reviews, 2010; 14: 31-55

[3] Wagner S, Rubin E. Economic implications of thermal energy storage for concentrated solar thermal power. Renewable Energy, 2014; 61: 81-95

[4] Hernández-Moro J, Martínez-Duart JM. CSP electricity cost evolution and grid parities based on the IEA roadmaps. Energy Policy, 2012; 41: 184-192

[5] González-Roubaud E, Pérez-Osorio D, Prieto C. Review of commercial thermal energy storage in concentrated solar power plants: Steam vs. molten salts. Renewable and Sustainable Energy Reviews, 2017; 80: 133-148

[6] Xu B, Li P, Chan C. Application of phase change materials for thermal energy storage in concentrated solar thermal power plants: A review to recent developments. Applied Energy, 2015; 160: $286-307$

[7] Seitz M, Cetin P, Eck M. Thermal Storage Concept for Solar Thermal Power Plants with Direct Steam Generation. Energy Procedia, 2014; 49: 993-1002

[8] Laing D, Bahl C, Bauer T, Lehmann D, Steinmann W. Thermal energy storage for direct steam generation. Solar Energy, 2011; 85: 627-633

[9] Jové A, Prieto C, Abujas C, Rodríguez-Sánchez A, Alguacil M. Heat storage method and system for a solar steam generation plant and solar steam generation plant. WO 2016/034754

[10] Palomo E, Khemis S, Mourand D, Noel F, Ho-Kon-Tiat V, Dauverge JL, Anguy Y, Prieto C, Jové A. Composite material for storing heat energy at high temperatures. EP 2444468 A1

[11] Jové A, Prieto C. Heat storage system and method for the charging and discharging thereof. WO 2014053677 A1

[12] Ruiz-Cabañas FJ, Jové A, Prieto C, Madina V, Fernández AI, Cabeza L. Materials selection of steam-phase change material (PCM) heat exchanger for thermal energy storage systems in direct steam generation facilities. Solar Energy Materials \& Solar Cells, 2017; 159: 526-535

[13] Design guidelines for the selection and use of stainless steel. Nickel development institute

[14] Klueh RL. Chromium-Molybdenum steels for fusion-reactor applications. Oak Ridge National Laboratory

[15] Klueh RL, Nelson AT. Ferritic/martensitic steels for next generation reactors. Journal of Nuclear Materials, 2007; 371: 37-52 
[16] Viswanathan R, Puerget R, Rao U. Materials technology for advanced coal power plants

[17] ASME Boiler and pressure vessel code. Section 2A Ferrous materials specification

[18] LiOH-KOH Phase Diagram.

http://www.crct.polymtl.ca/fact/phase_diagram.php?file=KOH-LiOH.jpg\&dir=FTsalt (accessed 31.08.2017)

[19] Achchaq F, Palomo E, Renaud A, Ben-Khemis S. Characterization of $\mathrm{Li}_{2} \mathrm{~K}(\mathrm{OH})_{3}$ as material for thermal energy storage at high temperature. The 13th International Conference on Energy Storage. Greenstock 2015

[20] Sigma Aldrich website www.sigmaaldrich.com (accessed 31.08.2017)

[21] ASTM G1-03. Standard practice for preparing, cleaning and evaluating corrosion test specimens, ASTM International

[22] ASTM G30-95. Standard Practice for Making and Using U-Bend Stress-Corrosion Test Specimens, ASTM International

[23] ASTM G58-85. Standard Practice for Preparation of Stress-Corrosion Test Specimens for Weldments, ASTM International

[24] Graydon JW, Kirk DW. The corrosion of carbon steel in aqueous lithium hydroxide under a hydrogen blanket. Canadian fusion fuels technology project CFFTP G-9045, 1990.

[25] Ivanov SO, Gorbatykh VP. The Effects of a Lithium-Ferritic Film on Slowing Down Corrosion Cracking of Heat-Exchange Tubes of Steam Generator at Nuclear Power Plants with VVER Reactors. Thermal Engineering, 2007; 54: 332-335

[26] Lim T, Hwang ER, Ha HY, Nam SW, Hong SA. Effects of temperature and partial pressure of $\mathrm{CO}_{2} / \mathrm{CO}$ on corrosion behaviour of stainless-steel in molten $\mathrm{Li} / \mathrm{Na}$ carbonate salt. Journal of Power Sources, 2000; 89: 1-6

[27] V.S. Sastri, E. Ghali, M. Elboujdaini. Corrosion, prevention and protection. Practical solutions, John Wiley \& Sons, 2007

[28] ASME Boiler and pressure vessel code. Section 2D Properties

[29] ASME Boiler and pressure vessel code. Section 8 DIv 1. Rules for the Construction of Pressure Vessels

[30] Steam oxidation on Cr-Mo steel tubes. Sumitomo metal industries Ltd. 805, 1443A, 1989. 